\title{
Growth Factor-dependent Initiation of DNA Replication in Nuclei Isolated from an Interleukin 3-dependent Murine Myeloid Cell Line
}

\author{
Nikhil C. Munshi and Theodore G. Gabig \\ Department of Medicine and Walther Oncology Center, Indiana University School of Medicine, Indianapolis, Indiana 46202
}

\begin{abstract}
To study the proliferative response of hematopoietic cells to growth factors at the molecular level, we developed a cell-free system for growth factor-dependent initiation of genomic DNA replication. Nuclei were isolated from the IL-3-dependent cell line NFS/N1-H7 after a 10-h period of IL-3 deprivation. Cytosolic and membrane-containing subcellular fractions were prepared from proliferating NFS/N1-H7 cells. Nuclei from the nonproliferating cells $( \pm I L-3)$ showed essentially no incorporation of $\left.{ }^{3} \mathrm{H}\right]$ thymidine during a $16-\mathrm{h}$ incubation with a mixture of unlabeled GTP, ATP, UTP, CTP, dGTP, dATP, dCTP, and $\left[{ }^{3} H\right] d T T P$. When the combination of $I L-3$, a cytosolic fraction, and a membrane-containing fraction from proliferating cells was added to nuclei from nonproliferating cells, a burst of $\left.{ }^{3} \mathrm{H}\right]$ thymidine incorporation into DNA began after a 12-h lag period, attained a maximal rate at $16 \mathrm{~h}$, and reached a level of 860 pmol thymidine $/ 10^{6}$ nuclei at $24 \mathrm{~h}$ (corresponding to replication of $\sim 56 \%$ total mouse genomic DNA). This DNA synthesis was inhibited $\sim 90 \%$ by the specific DNA polymerase $\alpha$ inhibitor aphidicolin. Deletion of a single cellular component or IL-3 from the system resulted in a marked reduction of DNA replication ('membrane, $80 \pm 4 \%$; 'cytosol, $90 \% \pm 4 \%$; ${ }^{-}$IL-3, $74 \pm 7 \%$ inhibition). This model requires a growth factor (IL-3), a sedimentable cell fraction containing its receptor and possibly additional membrane-associated components, and a cytosolic fraction. It appears to recapitulate the molecular events required for progression from early $G_{1}$ to $S$ phase of the cell cycle induced by IL-3 binding to its receptor. (J. Clin. Invest. 1990. 85:300-304.) cell-free system • DNA replication • growth factor $\cdot$ IL-3
\end{abstract}

\section{Introduction}

The hematopoietic growth factor IL-3, a $28-\mathrm{kD}$ glycoprotein secreted by activated $\mathrm{T}$-lymphocytes, promotes the prolifera-

A preliminary report of this work was presented at the 18th Annual Meeting of the International Society of Experimental Hematology in Paris, France, on 18 July 1989, and was published in abstract form [1989. Exp. Hematol. (NY). 17:354.(Abstr.)].

Address reprint requests to Dr. T. G. Gabig, Division of Hematology/Oncology, Department of Medicine, IUMC, Rm. 377, Clinical Bldg., 541 Clinical Drive, Indianapolis, IN 46223.

Received for publication 17 July 1989 and in revised form 18 Sep tember 1989.

J. Clin. Invest.

(c) The American Society for Clinical Investigation, Inc.

0021-9738/90/01/0300/05 \$2.00

Volume 85, January 1990, 300-304 tion and differentiation of early hematopoietic stem and progenitor cells in vitro $(1,2)$. Along with other cytokines that bind to plasma membranes, including IL-1 (3), colony-stimulating factor-1 (4), and erythroid burst-promoting activity (5), IL-3 may play an important role in the regulation of hematopoietic cell proliferation and differentiation in vivo. Murine IL-3-dependent cell lines derived from long-term bone marrow cultures have a single class of high-affinity cell-surface receptor for IL-3 (6). Chemical cross-linking studies of IL-3 with its cell-surface receptor indicate the receptor is a 140-150-kD protein that becomes phosphorylated on tyrosine within seconds of ligand binding $(7,8)$. As in other growth factor-dependent cells, IL-3 is required for progression beyond a critical point in early $G_{1}$ of the cell cycle in IL-3-dependent murine myeloid cell lines, and entry into $S$ phase occurs after a delay of $16 \mathrm{~h}$ after initial IL-3 exposure (9). Although recent studies suggest that the IL-3 receptor may be a tyrosine kinase (and/or activate a kinase cascade), the identity and biochemical functions of cytosolic phosphoproteins that appear within minutes of IL-3 stimulation (10), and their relationship to later biochemical events that result in progression through $G_{1}$ phase of the cell cycle and entry into $S$ phase, are entirely unknown. In the present studies, the murine IL-3-dependent cell line NFS/N1-H7, derived from retroviral-free long-term bone marrow cultures in vitro (11), was used to develop a cell-free model of growth factor-dependent initiation of DNA replication.

Important insight into the biochemical basis of hormoneor growth factor-stimulated cell proliferation has been obtained from genetic studies of cell-cycle-deficient yeast mutants $(12,13)$. While the generation of temperature-sensitive cell cycle-defective mutants in mammalian cells is feasible (14), segregation into classic genetic complementation groups by cell fusion and subsequent genetic analysis is technically more difficult than in fusion yeast. Thus a cell-free system reflecting the complete sequence of essential molecular events for growth factor-stimulated proliferation of mammalian cells would provide a useful model for genetic as well as biochemical analysis.

\section{Methods}

Reagents. McCoy's 5A media and penicillin-streptomycin were obtained from Gibco Laboratories (Grand Island, NY). Agarose type VII, glycerol, DTT, aphidicolin, and bromodeoxyuridine triphosphate $(\text { BrdUTP) })^{1}$ were obtained from Sigma Chemical Co. (St. Louis, MO). FBS was from HyClone Laboratories (Logan, UT). Natural murine

1. Abbreviation used in this paper: BrdUTP, bromodeoxyuridine triphosphate. 
IL-3 was from Genzyme Corp. (Boston, MA). Liquid paraffin was from Serva Fine Biochemicals Inc. (Garden City Park, NY). Triton X-100 was obtained from Research Products International Corp. (Mt. Prospect, IL). dATP, dCTP, dGTP, dTTP, ATP, CTP, GTP, and UTP were purchased from Boehringer Mannheim Biochemicals (Indianapolis, IN). $\left[{ }^{3} \mathrm{H}\right] \mathrm{dTTP}(\sim 80 \mathrm{Ci} / \mathrm{mmol})$ was from New England Nuclear Research Products (Boston, MA). Monoclonal mouse antiBrdU and tetramethylrhodamine isothiocyanate conjugated rabbit anti-mouse IgG was from DAKOPATTS (Copenhagen, Denmark). The other reagents were of the highest commercially available grade.

Cell culture. Characteristics of the murine myeloid cell line, NFS/N1-H7, used in these studies have been previously reported (11). The cells are dependent on both (FBS) and a source of murine IL-3 for proliferation and viability. The cell line was grown in McCoy's 5A media containing 10\% FBS and WEHI-3-conditioned medium as a source of IL-3. The cells were passaged twice weekly by $1: 10$ dilution in fresh medium adjusted to contain $\geq 500 \mathrm{U} / \mathrm{ml} \mathrm{IL-3}$. Cells were diluted to $10^{5} / \mathrm{ml}$ in fresh medium $48 \mathrm{~h}$ before harvesting for the preparation of nuclei or subcellular fractionation as described below.

Cell cycle analysis. NFS/N1-H7 cells, before or after IL-3 deprivation as indicated in the text, were stained with propidium iodide then analyzed for DNA content by fluorescence-activated cell sorting on a cell sorter (Epics 753; Coulter Electronics Inc., Hialeah, FL) by the method of Deitch et al. (15). The percent of cells in $S$ phase was calculated from the DNA histogram.

Preparation of encapsulated nuclei. Nuclei isolated from mammalian cells by standard techniques of cell disruption in high ionic strength buffers often display a high background rate of DNA polymerase $\beta$ repair (16). Although Xenopus laevis spleen cell nuclei provide a more native DNA template and have been used to study potential second messengers in mitogen-stimulated lymphocyte cytosol (17), we wished to avoid the use of amphibian nuclei, which may differ importantly from mammalian nuclei because they appear not to have sequence-specific origins of replication (18). We therefore employed the method of Jackson and Cook for isolation of agarose-encapsulated nuclei under isotonic conditions (19). This method has been shown to yield mammalian cell nuclei with a highly native, supercoiled DNA template freely accessible to molecules up to $1.5 \times 10^{8} \mathrm{D}$ and suitable for the study of replicative DNA synthesis (20). In brief, a $2.5 \% \mathrm{wt} / \mathrm{vol}$ solution of low-melting temperature agarose (Sigma type VII) was further purified by the addition of $10 \% \mathrm{wt} / \mathrm{vol}$ moist DEAE cellulose (DE52; Whatman Inc., Clifton, NJ) and incubation at $50^{\circ} \mathrm{C}$ for 30 $\mathrm{min}$. The DEAE cellulose and absorbed impurities were removed by centrifugation and $1.0-\mathrm{ml}$ aliquots of the supernatant agarose solution were sterilized by autoclaving.

NFS/N1-H7 cells were washed three times, resuspended in McCoy's medium containing $10 \%$ FBS but no IL-3, then incubated without $\mathrm{IL}-3$ at $37^{\circ} \mathrm{C}$ for $10 \mathrm{~h}$. The cells were then resuspended in $4 \mathrm{ml}$ of McCoy's $/ 10 \% \mathrm{FBS}$ at $2 \times 10^{7}$ cells $/ \mathrm{ml}$ and warmed to $37^{\circ} \mathrm{C}$. A premelted $1.0-\mathrm{ml}$ aliquot of $2.5 \%$ agarose was temperature equilibrated in a $39^{\circ} \mathrm{C}$ water bath, then rapidly mixed with $4 \mathrm{ml}$ of the cell suspension at $37^{\circ} \mathrm{C} .2 \mathrm{vol}(10 \mathrm{ml})$ of liquid paraffin oil was then added to the aqueous cell suspension and the mixture was vortexed for $30 \mathrm{~s}$ in a sealed 50-ml round bottom centrifuge tube. The resulting emulsion was rapidly cooled in a melting ice bath and the agarose-encapsulated cells were recovered in the pellet after centrifugation at $10,000 \mathrm{~g}$ for 10 min at $10^{\circ} \mathrm{C}$. The pelleted beads were resuspended in McCoy's media containing 10\% FBS (no IL-3) to a final volume of $8 \mathrm{ml}$, then lysed by the addition of $3 \mathrm{vol}(24 \mathrm{ml})$ of isotonic lysis buffer $(0.5 \% \mathrm{wt} / \mathrm{vol}$ Triton $\mathrm{X}-100,100 \mathrm{mM} \mathrm{KCl}, 25 \mathrm{mM}$ EDTA, $1 \mathrm{mM}$ DTT in $10 \mathrm{mM}$ Tris-HCl, $\mathrm{pH}$ 8.0). After incubation at $4^{\circ} \mathrm{C}$ for $1 \mathrm{~h}$, the beads containing nuclei were washed three times in isotonic wash buffer $(100 \mathrm{mM} \mathrm{KCl}, 25 \mathrm{mM}$ $\left(\mathrm{NH}_{4}\right)_{2} \mathrm{SO}_{4}, 1 \mathrm{mM}$ EDTA, $1 \mathrm{mM}$ DTT, $5 \%$ glycerol in $10 \mathrm{mM}$ Tris$\mathrm{HCl}, \mathrm{pH}$ 8.0). The final pellet ( $\sim 2 \mathrm{~g}$ wet $\mathrm{wt})$ was weighed, resuspended by addition of an equal volume of wash buffer $(\sim 2 \mathrm{ml})$, then divided into $0.5-\mathrm{ml}$ aliquots and stored at $-80^{\circ} \mathrm{C}$ until used in the nuclear replication assay. Since the cell density in the initial $0.5 \%$ agarose solution was $1.6 \times 10^{7} / \mathrm{ml}$, the final concentration of nuclei was calcu- lated to be $8 \times 10^{6} / \mathrm{ml}$ in the $1: 1$ final dilution of agarose beads. This assumes that $100 \%$ of the nuclei were encapsulated and may be an overestimate of the number of nuclei actually contained in the beaded agarose. Calculations of $\left[{ }^{3} \mathrm{H}\right]$ thymidine incorporation per $10^{6}$ nuclei were based on this assumption, and thus may represent underestimates of the true DNA replication rate.

Preparation of cytosolic and membrane-containing subcellular fractions. Proliferating NFS/N1-H7 cells were washed three times, resuspended at $10^{8}$ cells $/ \mathrm{ml}$ in $0.25 \mathrm{M}$ sucrose, $40 \mathrm{mM}$ Tris $\mathrm{pH} 8.0$, and immediately disrupted in a melting ice bath by two 15 -s bursts at $30 \%$ power from the microtip of a sonic dismembrator (model 300; Fisher Scientific Co., Pittsburgh, PA). This treatment efficiently disrupted $70-90 \%$ of the cells as judged by phase contrast microscopy. Intact cells and nuclei were removed from the sonicate by centrifugation at $1,200 \mathrm{~g}$ for $10 \mathrm{~min}$. The postnuclear supernatant was then centrifuged in a swing-out rotor (SW 55; Beckman Instruments, Inc., Fullerton, CA) at $200,000 \mathrm{~g}$ for $45 \mathrm{~min}$ at $4^{\circ} \mathrm{C}$. The supernatant fraction, referred to subsequently as the "cytosolic" fraction, was carefully aspirated and stored at $-80^{\circ} \mathrm{C}$ in aliquots until used in the replication assay. The pellet fraction referred to subsequently as the "membrane-containing fraction," contained besides plasma membrane other sedimentable subcellular organelles such as endoplasmic reticulum, Golgi, and mitochondrial membranes. This fraction was resuspended in $0.25 \mathrm{M}$ sucrose, $40 \mathrm{mM}$ Tris- $\mathrm{HCl}, \mathrm{pH} 8.0$, by gentle hand homogenization in a glass homogenizer with a Teflon pestle and stored as aliquots at $-80^{\circ} \mathrm{C}$ until used in the DNA replication assay.

DNA replication assay. Assays were initiated by the addition of 1.4 $\times 10^{5}$ nuclei to a replication mixture containing the following components in a final volume of $80 \mu \mathrm{l}: 1.25 \mathrm{mM}$ ATP; $0.1 \mathrm{mM} \mathrm{CTP,} \mathrm{GTP,}$ and UTP; $0.25 \mathrm{mM}$ dATP, dGTP, dCTP, and dTTP containing 1.5 $\mu \mathrm{Ci}\left[{ }^{3} \mathrm{H}\right.$ ]dTTP; $25-100 \mu \mathrm{g} / \mathrm{ml}$ cytosolic protein; $100 \mu \mathrm{g} / \mathrm{ml} \mathrm{membrane}$ protein; $100 \mathrm{mM} \mathrm{KCl} ; 25 \mathrm{mM}\left(\mathrm{NH}_{4}\right)_{2} \mathrm{SO}_{4} ; 1 \mathrm{mM}$ EDTA; $1 \mathrm{mM} \mathrm{DTT}$; $5 \% \mathrm{wt} / \mathrm{vol}$ glycerol; $1 \%$ penicillin-streptomycin in $10 \mathrm{mM}$ Tris- $\mathrm{HCl}$, pH 8.0. The mixture was incubated at $37^{\circ} \mathrm{C}$ in sealed $1-\mathrm{ml}$ polypropylene microfuge tubes. At the indicated times the reaction was stopped by addition of $200 \mu \mathrm{l}$ of a $2 \% \mathrm{wt} / \mathrm{vol}$ SDS solution and $50 \mu \mathrm{g}$ salmon sperm carrier DNA. Samples were immediately precipitated with $10 \%$ TCA and collected by vacuum filtration on GF/C filters. The filters were washed with $10 \%$ TCA and then absolute ethanol. Radioactivity contained on the dried filters was measured by scintillation counting in Ready Value scintillation fluid (Beckman Instruments, Inc.) in a Beckman LS 6800 liquid scintillation counter.

The minimal amount of cytosolic protein capable of supporting IL-3-stimulated DNA replication was variable from one preparation to another and was determined in preliminary experiments for each cytosol preparation. In some preparations of cytosols, high amounts of cytosolic protein were capable of stimulating DNA synthesis in the absence of IL-3 and membrane protein. These high concentrations were not used in the present experiments.

Labeling of nuclei with BrdU and anti-BrdU Ab. Conditions in the DNA replication assay were identical to those described above except that $100 \mu \mathrm{M}$ BrdUTP was substituted for dTTP. After $16 \mathrm{~h}$ incubation at $37^{\circ} \mathrm{C}$, the beaded nuclei were smeared on glass slides and fixed with $100 \%$ methanol for $5 \mathrm{~min}$ at $-20^{\circ} \mathrm{C}$ followed by denaturation with 1.5 $\mathrm{M} \mathrm{HCl}$ for $\mathbf{3 0}$ min at room temperature. Staining with anti-BrdU Ab was essentially as described by Gratzner (21). After three washes in PBS, the fixed nuclei were reacted with mouse monoclonal anti-BrdU antibodies (DAKOPATTS) at 1:20 dilution for $1 \mathrm{~h}$ at $37^{\circ} \mathrm{C}$. The slides were washed five times with PBS then reacted with rhodamine-labeled rabbit anti-mouse IgG (DAKOPATTS) at 1:20 dilution for $1 \mathrm{~h}$ at $37^{\circ} \mathrm{C}$. The slides were washed again five times in PBS, mounted, and photographed under light or fluorescent microscopy.

\section{Results}

Cellular responses to IL-3 deprivation. The progressive decline in cell proliferation and cell viability after removal of IL-3 has been well documented in a variety of IL-3-dependent cell lines 
$(2,9)$. The murine myeloid cell line used in the present study, NFS/N1-H7, also showed a loss of viability (24\% viable compared with control, measured by trypan blue dye exclusion) and decline in proliferative rate $(1.2 \%$ control measured by $\left[{ }^{3} \mathrm{H}\right]$ thymidine uptake) after IL-3 deprivation for $24 \mathrm{~h}$. As analyzed by fluorescence-activated cell sorting, the percent of cells in S phase declined from $20-25 \%$ during log growth in IL-3-containing media to $10 \%$ after a 10 -h period of IL-3 deprivation. When a source of IL-3 was restored after a 10-h deprivation period, the percent cells in $\mathrm{S}$ phase declined further to $5 \%$ at $8 \mathrm{~h}$, then increased to $65 \%$ at $12-14 \mathrm{~h}$ after readdition of IL-3. Thus deprivation of IL-3 for $10 \mathrm{~h}$ did not result in complete cell-cycle synchronization after readdition of IL-3, but it did result in a significant decline of S phase cells after deprivation, which was followed by a threefold increase in S phase cells $12 \mathrm{~h}$ after IL-3 restoration.

DNA synthesis in nuclei isolated from NFS-H7 cells. Nuclei prepared from NFS/N1-H7 cells that had been deprived of IL-3 for a period of $10 \mathrm{~h}$ were examined for DNA synthesis in the cell-free replication assay. In the presence (Fig. 1, open circle) or absence of $500 \mathrm{U} / \mathrm{ml} \mathrm{IL-3,} \mathrm{these} \mathrm{nuclei} \mathrm{incorporated}$ $<50$ pmol $\left[{ }^{3} \mathrm{H}\right]$ thymidine $/ 10^{6}$ nuclei from $\left[{ }^{3} \mathrm{H}\right]$ dUTP after 24 $h$. When cytosolic and membrane-containing subcellular fractions were added to the cell-free DNA replication system in the presence of $500 \mathrm{U} / \mathrm{ml} \mathrm{IL-3} \mathrm{(Fig.} \mathrm{1,} \mathrm{solid} \mathrm{circles),} \mathrm{incorporation}$ of $\left[{ }^{3} \mathrm{H}\right]$ thymidine remained at background levels until $\sim 12 \mathrm{~h}$, when $\left[{ }^{3} \mathrm{H}\right]$ thymidine incorporation into DNA increased abruptly. The rate of $\left[{ }^{3} \mathrm{H}\right]$ thymidine incorporation was maximal at $14-16 \mathrm{~h}$ and reached a level of $860 \mathrm{pmol} / 10^{6}$ nuclei at $24 \mathrm{~h}$. The 12-h lag period in the cell-free system is thus comparable to the 12-14-h lag period between addition of IL-3 and entry into $S$ phase of intact NFS/N1-H7 cells.

As shown in Fig. 2, deletion of the cytosolic or membranecontaining fraction, or deletion of IL-3, resulted in a significant decrease in DNA synthesis in the cell-free system. Additionally the specific DNA polymerase $\alpha$ inhibitor, aphidicolin, caused $>90 \%$ inhibition of DNA synthesis indicating that the

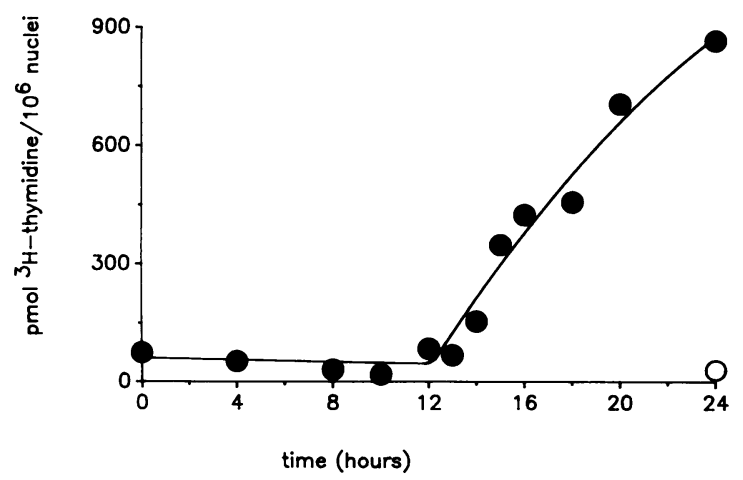

Figure 1. Time course of DNA replication in NFS/N1-H7 nuclei. Agarose-encapsulated nuclei were prepared from NFS/N1-H7 cells after a 10-h period of IL-3 deprivation and used as a DNA template in the cell-free replication assay which was stopped at the indicated times as described in Methods. The solid circles represent the mean thymidine incorporation per $10^{6}$ nuclei, of duplicate samples that contained $1.4 \times 10^{5}$ nuclei, $100 \mu \mathrm{g} / \mathrm{ml}$ cytosolic protein, $100 \mu \mathrm{g} / \mathrm{ml}$ membrane protein, and $500 \mathrm{U} / \mathrm{ml} \mathrm{IL-3.} \mathrm{The} \mathrm{open} \mathrm{circle} \mathrm{at} 24 \mathrm{~h}$ was the mean of a duplicate assay containing $1.4 \times 10^{5}$ nuclei and 500 $\mathrm{U} / \mathrm{ml}$ IL-3 but no cytosolic or membrane protein. The time course shown is a representative one of four experiments.

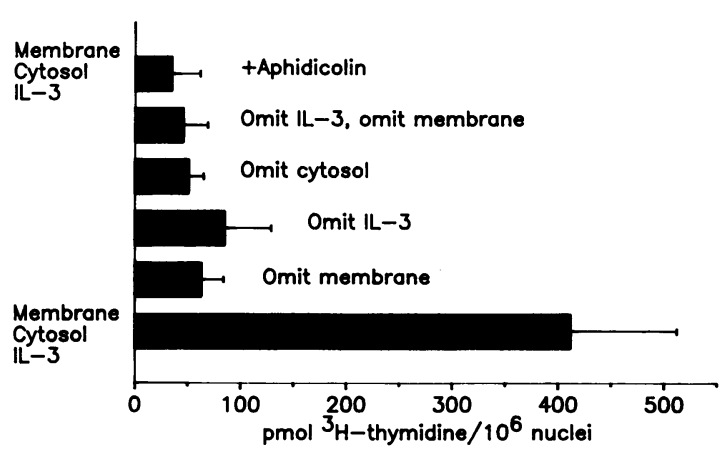

Figure 2. The essential role of IL-3, cytosolic, and membrane-containing subcellular fractions, and DNA polymerase $\alpha$ activity for cellfree DNA replication. Components of the cell-free system were prepared and used in the cell-free DNA replication assay as described in Methods. All replication assays were stopped at $16 \mathrm{~h}$ and results are mean \pm 1 SD of three to five separate experiments. Components of the standard cell-free replication assay were omitted, as indicated, by substitution of the appropriate buffer blank. Aphidicolin was added at $40 \mu \mathrm{M}$ final concentration at initiation of the cell-free replication assay; this concentration has been shown to inhibit DNA primase as well as DNA polymerase $\alpha$ activity (19). Reduction in $\left[{ }^{3} \mathrm{H}\right]$ thymidine uptake by omission of components of cell-free system or addition of aphidicolin is significant with $P$ value of $<0.005$ by the paired $t$ test.

cell-free system reflected replicative DNA synthesis by DNA polymerase $\alpha$, rather than aphidocolin-insensitive DNA repair by DNA polymerase $\beta$. When nuclei were omitted from the $16-\mathrm{h}$ assay, $<5$ pmol $\left[{ }^{3} \mathrm{H}\right]$ thymidine was recovered on the glass filter from an amount of cytosol, membrane fraction, and IL-3 equivalent to that used in a standard assay containing 1.4 $\times 10^{5}$ nuclei.

Since mouse genomic DNA contains $\sim 3 \times 10^{9}$ bp and $30 \%$ thymidine, the extent of DNA replication in the cell-free system represented $\sim 27 \%$ of total genomic DNA at $16 \mathrm{~h}$ and $56 \%$ at $24 \mathrm{~h}$ (Figs. 1 and 2). To determine whether partial DNA replication was due to the ability of only a fraction of the isolated nuclei to replicate DNA, we examined the nuclear immunofluorescence staining pattern with rhodamine-labeled anti-BrdU antibody (21) after substitution of BrdUTP for dTTP in the cell-free system. As shown in Fig. 3, $A$ and $B$, when the cytosolic fraction, membrane fraction, and IL-3 were present, $>80 \%$ of the encapsulated nuclei showed diffuse fluorescence with anti-BrdU at $16 \mathrm{~h}$, although the intensity of staining was variable. In contrast, when the cytosolic and membrane-containing fractions were omitted, $<5 \%$ of the encapsulated nuclei showed any visible immunofluorescence with rhodamine-labeled anti-BrdU at $16 \mathrm{~h}$ (Fig. 3, $C$ and $D$ ). Thus although DNA replication in the standard assay was incomplete, it appeared that the majority of encapsulated nuclei were capable of initiating DNA synthesis in response to IL-3 plus the cytosolic and membrane-containing cellular fractions. From the rate of DNA replication in Fig. 1, it can be estimated that complete replication of genomic DNA would require $21 \mathrm{~h}$ in the cell-free system, a figure that is considerably slower than the $10-12 \mathrm{~h}$ estimated for completion of $\mathrm{S}$ phase in intact NFS/N1-H7 cells.

\section{Discussion}

The present model for cell-free initiation of replicative DNA synthesis has three characteristics that are unique compared 

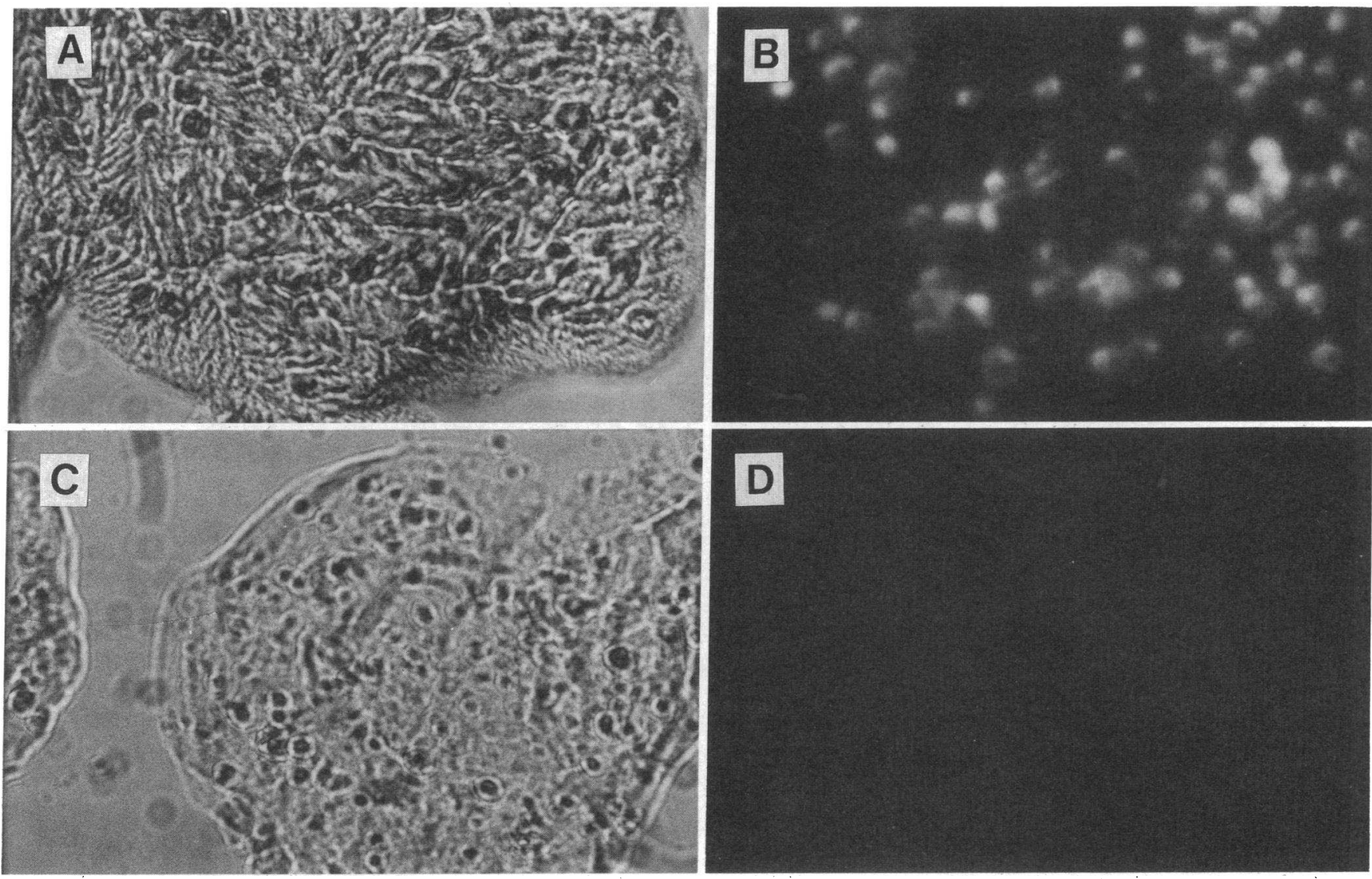

Figure 3. Incorporation of BrdU from BrdUTP into nuclear DNA. The cell-free DNA replication assay was conducted as described except that $100 \mu \mathrm{M}$ BrdUTP was substituted for dTTP. At $16 \mathrm{~h}$ the encapsulated nuclei were fixed on glass slides, reacted with anti-BrdU MAb, then a second rhodamine-conjugated $\mathrm{Ab}$, and photographed under light or fluorescence microscopy as described by Gratzner (21). $A$ is a $100 \times$ light photomicrograph of agarose-encapsulated nuclei from a cell-free replication containing IL-3, cytosolic, and membrane-containing subcellular fractions. $B$ is the same $100 \times$ field as $A$ photographed by fluorescence microscopy. $C$ is a $100 \times$ light photomicrograph of agarose-encapsulated nuclei from a cell-free replication assay containing IL-3 but no membrane-containing or cytosolic subcellular fractions. $D$ is the same $100 \times$ field as $C$ photographed by fluorescence microscopy. Individual agarose beads contain $40-60$ nuclei.

with currently available systems for the study of cell-cycle regulation and DNA replication. (a) Components of the system are derived from a single mammalian cell type. $(b)$ The system is responsive to a growth factor (IL-3) known to be an essential stimulus for progression from $G_{0} / G_{1}$ to $S$ phase of the cell cycle in the intact cell. $(c)$ The cell-free system allows a direct biochemical approach to study essential intermediate signals between growth factor-receptor binding at the plasma membrane and the nuclear response. The characteristics of this cell-free system thus require discussion in the context of other currently available models of cell-cycle control and DNA replication.

The replication of SV40 virus within mammalian cells has been extensively studied as a model for essential proteins, cofactors, and enzymes comprising the replicase complex for bidirectional viral DNA replication (12). Although this system requires only one protein of viral origin, large $\mathrm{T}$ antigen (22), as a DNA sequence-specific initiator, it is not clear whether SV40 replication mimics chromosomal replication because more than one round of SV40 replication may occur per host cell cycle (12).

Other studies have focused on growth factor-stimulated initiation of DNA synthesis by using nuclei from Xenopus laevis spleen cells (17) as a native DNA template. However, since Xenopus chromosomes may not have specific origins of replication (18), it is not clear whether stimulation of Xenopus nuclear replication by subcellular fractions from mitogenstimulated mammalian cells reflects critical cell-cycle control mechanisms operative in mammalian cells.

The yeast system is probably the most powerful tool for the study of cell-cycle control and initiation of DNA synthesis in eukaryocytic cells. Through genetic studies of cell-cycle-deficient yeast, many critical genes controlling cell-cycle progression in response to external (nutrient) signals have been discovered (reviewed in references 12 and 13). Remarkably, many of the important cell-cycle regulatory yeast gene products have sequence and/or functional homology with mammalian cell counterparts (23). The ability to segregate cellcycle-deficient yeast mutants into classical genetic complementation groups by cell fusion has been an important feature of the yeast system that, due to low fusion efficiency, cannot be duplicated in mammalian cell systems. However, the mammalian cell-free system described here is amenable to the direct assignment of genetic complementation groups without cell fusion, simply by combining complementary cell fractions directly in the nuclear replication assay. Additionally, the mam- 
malian cell-free system allows the biochemical study of early or intermediate signals that may be specifically generated in response to mammalian growth factors or hormones.

\section{Acknowledgments}

Special thanks to Dr. H. Scott Boswell for helpful discussion and for providing the NFS/N1-H7 cell line for these studies, and to Stephanie Moore for typing the manuscript.

This work was supported by grant CA 45677 from the National Institutes of Health. Dr. Munshi was supported by a training grant from the National Cancer Institute.

\section{References}

1. Ihle, J. N., J. Keller, L. Henderson, F. Klein, and E. Palaszynski. 1982. Procedures for the purification of interleukin 3 to homogeneity. J. Immunol. 129:2431-2436.

2. Ihle, J. N., J. Keller, S. Oroszlan, L. E. Henderson, T. D. Copeland, F. Fitch, M. B. Prystowsky, E. Goldwasser, J. W. Schrader, E. Palaszynski, M. Dy, and B. Lebel. 1983. Biological properties of homogeneous interleukin 3. I. Demonstration of WEHI-3 growth factor activity, mast cell growth factor activity, $P$ cell stimulating factor activity, colony-stimulating factor activity, and histamine-producing cell stimulating factor activity. J. Immunol. 131:282-287.

3. Kurt-Jones, E. A., D. I. Beller, S. B. Mizel, and E. R. Unanue. 1985. Identification of a membrane-associated interleukin 1 in macrophages. Proc. Natl. Acad. Sci. USA. 82:1204-1208.

4. Rettenmier, C. W., M. F. Roussel, R. A. Ashmun, P. Ralph, K Price, and C. J. Sherr. 1987. Synthesis of membrane-bound colonystimulating factor 1 (CSF-1) and down modulation of CSF-1 receptors in NIH3T3 cells transformed by cotransfection on human CSF-1 and c-fms (CSF-1 receptor) genes. Mol. Cell. Biol. 7:2378-2387.

5. Feldman, L., C. M. Cohen, M. A. Riordan, and N. Dainiak. 1987. Purification of a membrane-derived human erythroid growth factor. Proc. Natl. Acad. Sci. USA. 874:6775-6779.

6. Palaszynski, E. W., and J. N. Ihle. 1983. Evidence for specific receptors for interleukin 3 on lymphokine-dependent cell lines established from long-term bone marrow cultures. J. Immunol. 132:18721878.

7. Koyasu, S., A. Tojo, A. Miyajima, T. Akiyama, M. Kasuga, A Urabe, J. Schreurs, K. Arai, F. Takaku, and I. Yahara. 1987. Interleukin 3-specific tyrosine phosphorylation of a membrane glycoprotein of $M_{r} 150,000$ in multi-factor-dependent myeloid cell lines. $E M B O$ (Eur. Mol. Biol. Organ.) J. 6:3979-3984.

8. Isfort, R. J., D. Stevens, W. S. May, and J. N. Ihle. 1988. Inter- leukin 3 binds to a $140-\mathrm{kDa}$ phosphotyrosine-containing cell surface protein. Proc. Natl. Acad. Sci. USA. 85:7982-7986.

9. Kelvin, D. J., S. Chance, M. Shreeve, A. A. Axelrad, J. A. Connolly, and D. McLeod. 1986. Interleukin 3 and cell cycle progression. J. Cell. Physiol. 127:403-409.

10. Isfort, R., R. D. Huhn, A. R. Frackelton, Jr., and J. N. Ihle. 1988. Stimulation of factor-dependent myeloid cell lines with interleukin 3 induces tyrosine phosphorylation of several cellular substrates. J. Biol. Chem. 263:19203-19209.

11. Boswell, H. S., M. A. Harrington, G. S. Burgess, T. L. Nahreini, H. G. Derigs, T. D. Hodges, D. English, C. D. Crean, and T. G. Gabig. 1989. A mutant RAS gene acts through protein kinase $C$ to augment interleukin-3 dependent proliferation in a fastidious immortal myeloid cell line. Leukemia (Baltimore). 3:662-668.

12. Campbell, J. L. 1986. Eukaryocytic DNA replication. Annu. Rev. Biochem. 55:733-771.

13. Dunphy, W. G., and J. W. Newport. 1988. Unraveling of mitotic control mechanisms. Cell. 55:925-928.

14. Thompson, L. H., R. Mankovitz, R. M. Baker, J. E. Till, L. Siminovitch, and G. F. Whitmore. 1970. Isolation of temperaturesensitive mutants of L-cells. Proc. Natl. Acad. Sci. USA. 66:377-384.

15. Deitch, A. D., H. Law, and R. D. White. 1982. A stable propidium iodide staining procedure for flow cytometry. J. Histochem. Cytochem. 30:967-972.

16. Jackson, D. A., and P. R. Cook. 1986. Replication occurs at a nucleoskeleton. EMBO (Eur. Mol. Biol. Organ.) J. 5:1403-1410.

17. Das, M. 1980. Mitogenic hormone-induced intracellular message: assay and partial characterization of an activator of DNA replication induced by epidermal growth factor. Proc. Natl. Acad. Sci. USA. 77:112-116.

18. Harland, R. M., and R. A. Laskey. 1980. Regulated replication of DNA microinjected into eggs of Xenopus laevis. Cell. 21:761-771.

19. Jackson, D. A., and P. R. Cook. 1985. A general method for preparing chromatin containing intact DNA. EMBO (Eur. Mol. Biol. Organ.) J. 4:913-918.

20. Jackson, D. A., and P. R. Cook. 1986. A cell-cycle dependent DNA polymerase activity that replicates intact DNA in chromatin. $J$. Mol. Biol. 192:65-76.

21. Gratzner, H. G. 1982. Monoclonal antibody to 5-bromo- and 5-iododeoxyuridine: a new reagent for detection of DNA replication. Science (Wash. DC). 218:474-475.

22. Decker, R. S., M. Yamaguchi, R. Possenti, and M. L. DePamphilis. 1986. Initiation of simian virus 40 DNA replication in vitro: aphidicolin causes accumulation of early-replicating intermediates and allows determination of the initial direction of DNA synthesis. $\mathrm{Mol}$. Cell. Biol. 6:3815-3825.

23. Draetta, G., L. Brizuela, J. Potashkin, and D. Beach. 1987. Identification of p34 and p13, human homologs of the cell cycle regulators of fission yeast encoded by $\mathrm{cdc}^{+}$and suc1 $1^{+}$. Cell. 50:319-325. 